\title{
Grounds for optimism
}

\section{A summit of Africa's leaders marks a deepening commitment to science and technology in the continent.}

N ext week, heads of states in the African Union will gather for a summit in Addis Ababa (see page 356). The meeting's two main themes are climate change and the harnessing of science and technology for development - making this Africa's highestpowered gathering on science in years.

Issues to be discussed include a proposal for an Africa-wide science fund (broadly analogous to the European Union's Framework programme), plans for new research centres, and a biotechnology strategy for Africa. This last issue is an attempt to reconcile supporters and critics of agricultural biotechnology and establish some level of consensus on research, commercialization and regulation. Also on the table is an idea to establish a presidential science council, at which Africa's heads of state would be briefed on relevant issues in science and development, and review African Union decisions on science policy.

These proposals will be vigorously debated at the Addis summit. Some countries - notably Nigeria and South Africa, the two nations with the most money - are still to be convinced of the need for an Africa-wide science fund. At the same time, civil servants and science ministers across the continent are nervous about the idea of a presidential council, as they perceive (not unreasonably) that it could interfere with their own organization, the newly established African Ministerial Council on Science and Technology, also a component of the African Union.

The idea for a presidential council is not new: it was also put forward and agreed at the last African leaders' summit to deal extensively with science almost two decades ago. The inspiration that time came from Kenyan entomologist Thomas Odhiambo, who used his legendary charm and influence to persuade heads of state that they should meet periodically with scientists. One of his strongest supporters was Nigeria's current elected president Olusegun Obasanjo, who was then the nation's military ruler. Nigeria has the largest population of any nation in Africa - around 130 million - and its oil revenues have increased its potential to exert influence across the continent.

The rationale behind the presidential council is straightforward: if you want to get anything done, you need access to the people at the top. Yet the omnipotence of typical participants in the 1980s proved to be the idea's undoing last time, after just three meetings between scientists and presidents. "You couldn't tell who was about to be overthrown in a coup, or who was next in line to be killed. There was no continuity in our work," one of the organizers tells Nature.

Times have changed. Obasanjo's keenness on science and innovation is shared by several of his fellow elected presidents, notably Abdoulaye Wade of Senegal, Bingu wa Mutharika of Malawi, and Rwanda's Paul Kagame. Many more countries in Africa also have elected governments, resulting in the healthy involvement of fresh constituencies in scientific decision-making.

Nowhere is this more apparent than in the build-up to next week's summit. Representatives of many different interests, including scientists, non-governmental organizations, civil servants, agencies of the United Nations, philanthropies and the media, have been free to scrutinize and influence the summit's agenda. They were encouraged to do so by the African Union, which is loosely based on the European Union and may be much better placed than its predecessor - the Organization of African Unity - to push forward meaningful initiatives in science and other spheres.

But international politics could still throw the summit's plans to attend to scientific matters off course. Ethiopia, the summit's host nation, is currently
"The planners of the summit want Africa's leaders to think about creating conditions in which war and poverty are the exception, rather than the rule." engaged in a contentious military intervention in neighbouring Somalia, and the leaders' response to that situation could yet come to dominate the meeting.

So far, however, the organizers of the Addis summit have conceded no changes in its agenda, reflecting their determination that although the Somalia situation must be discussed, it should not dominate proceedings. This is as it should be. The planners of the Addis summit want Africa's leaders to think about the long term, and about creating conditions within which war and poverty are the exception, rather than the rule. They should not be distracted from that goal.

\section{Clock-watching}

\section{Time for a change?}

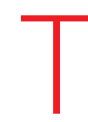

he clock face around which our minutes tick away is perhaps the single most potent symbol of the industrial era. It is the clock that allowed modern life to be cut precisely into the segments that the workplace requires and the individual seeks to protect.

On wrists and office walls, hanging from the vaults of railway stations, or squatting toadlike by the bedside to curtail our sleep, the clock and its face have become the near-universal embodiment of the always felt but hitherto seldom quantified march of time. As a result, it cries out for manipulation - whether by the hurried commuter who fools himself into punctuality by setting his watch five minutes fast, or by a government changing the clocks of a nation to make the most of the daylight hours.

There was a time - 1911, as it happens - when this journal was strongly against the latter practice, as embodied in the then radical idea of introducing daylight-saving time to Britain. Rather highmindedly, we thought that "the scheme is unworthy of the dignity of a great nation, and if it were made compulsory by legislation, it 